\title{
Lake Athabasca Records of Interest
}

\section{Compiled by Stuart Houston, Saskatoon}

Very little is known of bird disitribution in the northern third of Saskatchewan. The results of two important collecting trips to Lake Athabasca, by Francis Harper in 1920 and by T. M. Shortt in 1945, unfortunately have not appeared in print. I recenitly had the privilege of checking the Saskatchewan ranges for the forthcoming new edition of Peterson's Field Guide to the Western Birds and realized more acutely than ever how little we know of the breeding ranges of birds in northern Saskatchewan. I wrote to Harper and Shortt concerning certain key species and I felt the information they supplied should be !laced on record.

Arctic Loon: One seen August 15, 1920, by Francis Harper on the water about a mile east of Moose Island on the north shore cf Lake Athabasca (long $108^{\circ} 20^{\prime}$, east of the former Goldfields townsite). Harper states: "It dove a couple of times at my approach and disappeared then for good, perhaps around an island. I clearly saw the smoke-gray of its occiput." Shortt did not record this species in 1945. There are no known breeding records for Saskatchewan.

Black-billed Magpie: Thomas Heaslip listed this species in his list of birds seen at Uranium City. (Blue Jay 17: 58, 1959). Correspondence with Heaslip has disclosed that this bird was a winter wanderer that staycd in the vicinity of the Lorado "Mining Camp garbage dump for three weeks in November, 1957. 'This is the first published record of this species for the northern third of Saskatchewan, though other stragglers have occurred at Brochet, Manitoba (see Snyder, Can. Field-Nat. 49: 152, 1935, where Brochet is incorrectly said to be in Saskatchewan). Other stragglers must go even further north, as three were shot by Joseph Yank in 1943-44 on the Dubawnt River, 50 miles southeast of Dubawnt Lake, in the Northwest Territories, and some 150 miles north of the northern boundary of Saskatchewan. (Rand, Can. Field-Nat. 59: 45, 1945).

Blackpoll Warbler: T. M. Shortt collected a nest and one flightless juvenile at Fond-du-lac on July 21, 1945. This would appear ito constitute the first and only nesting record of this species for Saskatchewan.

Common Redpoll: On July 21, 1945, at Fond-du-las, Lake Athabasca, T. M. Shortt collected a male (with still large testes) and a female (with ruptured ovarian follicles) within a few yards of each other. He did not find a nest or young birds. There are no Saskatchewan breeding records lor this species.

Red Crossbill: On both July 15 and July 16, 1945, T. M. Shortt collected a family group of male, female, and two flying young. This was in one of the most extensive pine areas that he encountered and Shortt presunies that they nested nearby. However, the young were fully developed, and it is possible that they had llown some distance. Although there are summer records for Emma Lake, Prince Albert, Nipawin, and the Cypress Hills, there are no definite breeding records of this species for Saskatchewan.

\section{Some Saskatchewan Bird Observations}

\section{by Lawrence $\mathbf{H}$. Walkinshaw, Battle Creek, Michigan}

During late May and early June, 1947, W. A. Tholen and I visited central Saskatchewan. For several days we were at Yorkton; we spent another few days at Nipawin. From June 6 to 11 we were at Fishing Lake, 75 miles northwest of Nipawin. From June 14 through. Tune 16 we were 3-6 miles northwest of Snowden. Here we had seen some good marsh areas from the air.
At Fishing Lake we had no transportation so had to go by foot or in the lake itself by boat. We saw 74 species of birds right around the lake. Following are some of the more important:

Red-necked Grebe (Podiceps grisegena). A massive floating nest found June 10 , was built in two feet of water amongst the tules of the west side of the lake and contained 3 
eggs (measuring 55 by $36.5 ; 52.8$ by 36.5 and 54 by $36.4 \mathrm{~mm}$.). Two other nests were still empty. We observed six birds that one day.

Lesser Scaup (Aythya affinis). Four to 8 birds observed daily. Two nests were found on a boggy island in the beaver pond on June 10. One had 7 eggs (average 58.8 by 40.1 $\mathrm{mm}$.$) ; the other had only one egg.$

Spruce Grouse (Canachites canadensis). Nest and 7 eggs, June 6 (See Wilson Bulletin, 1948, 60:118).

Sora (Porzana carolina). A pair had a nest along the edge of the beaver pond. The incubating parent went by me with her wings drooping, and calling a low sharp 'Keee.' She was soon followed by her mate. The nest was built of sedges in sedges in $21 \mathrm{~cm}$. of water hidden under some dead spruce branches. The 10 eggs averaged in measurements, $33.12(31-34.5)$ by 23.41 (22.6-24.0) m.m. and 9.77 grams in weight. (I found another nest June 14 at Snowden, T53, R19W2, Sect. 2 in a cattail marsh. This nest had 12 eggs averaging in measurements, 31.07 (29.2-33.5) by $22.3(20.7-23.2) \mathrm{mm}$., and in weight, 7.7 (6.5-8.4) grams.)

Greater Yellowlegs (Totanus melanoleucus). 1-3 birds daily); $\mathrm{A}$ male was taken June 7 (Univ. Mich. Mus. Zool.), weight 195.8 grams; measurements, wing, $189 \mathrm{~mm}$; tail, $80 \mathrm{~mm}$.,; ex. cul., $57 \mathrm{~mm}$.

Killdeer, Wilson's Snipe, Spotted Sandpiper (nest and 2 eggs, June 8; 3 eggs June 9-10) and Solitary Sandpiper were also observed.

Bonaparte's Gull (Larus philadelphia). A male was taken June 7, which weighed 202.2 grams. It measured: wing, 257; tail, 95; ex. cul., $32 \mathrm{~mm}$. We observed 2-12 birds daily.

Common Tern (Sterna hirundo). Four birds abserved on June 9, of which one was taken (UMMZ). Weight, 133.2 grams. Measurements: wing, 267; tail, 137; tar., 20; ex. cul., $35 \mathrm{~mm}$. Two were observed June 10.

Black Tern (Chlidonias niger). Two to 16 observed daily.

Boreal Owl (Aegolius funereus richardsoni). A male was collected from dense white spruce forest, June 9. Weight, 118.6 grams. It measured: wing, 171; tail, 105; ex. cul., $20 \mathrm{~mm}$. (UMMZ).
Canada Jay (Perisoreus canadensis). Six to 12 birds around our cabin daily ( 52 cibserved on 6 diays). (Also observed 2 daily at Snowden, June 13-16. inc.).

Boreal Chickadee (Porus hudsonicus). Two to 4 birds cibserved daily. A nest with 5 eggs was found June 10 built 8 f.t. up in a 4-inch, dead white birch about 20 f.t. out in the beaver pond.

Warblers cibsırved at Fishing Lake included: Black and White (5 on two days); Tennessee ( 3 cn two days); Yellow ( 7 on four days); Cape May (Dendroica tigrina) (male collecited, June 7. Weight 10.0 grams; Measurements: wing, $65.5 \mathrm{~mm}$; tail, $46 \mathrm{~mm}$.; tarsus, $15.5 \mathrm{~mm}$.; ex. cul., 10 mm:) ; Myrtle (25 on six days); Bay-breasted ( 2 on June 6 ); Blackpoll (1 on June 10); Palm (1 on June 11); Ovenbird (10 on four days); Water Thrush ( 7 on three days); and Redstart (3 on two days).

Brown-headed Cowbird (Molothrus ater). A male taken south of Fishing Lake, June 6, weighed 51.1 grams, and measured: wing, $113 \mathrm{~mm}$; tail, 79 mm., tarsus, $27 \mathrm{~mm}$.; ex. cul. $17 \mathrm{~mm}$. At Fishing Lake 11 birds were observed on five days.

The Slate-colored Junco birds), Chipping Sparrow (26 birds), and the Song Sparrow (21 birds) were observed daily and the commonest sparrows. The Clay-colored Sparrow (Spizella pallida) was also found ( 3 birds in two days). (At Nipawin, this species was very common. Maurice Street and I found four nests, June 12, with 4, 4, 4 and 5 eggs respectively.. The eggs averaged in measurements: 17.02 (15.8$18.0)$ by $13.04(12.8-13.4)$ mm., and in weight 1.45 grams. The nests were all built in small spruces in the very dense part, averaging $27 \mathrm{~cm}$. (16-43) aibove ground.

In addition to the notes given above I observed 'at Snowden the following birds: Pied-billed Grebe (nest, 7 eggs); Horned Grebe, nest wtih 6 eggs (averaged in measurement $43.8(40.9-48.5)$ by 30.5 (30$31.5) \mathrm{mm}$., and in weight 27.0 grams.); Green-wing Teal, 2 broods of young on June 14,8 newly hatched young; June 15,9 young a few days old; Pintail female with brood of 7 young, June 15; Sandhill Crane (Grus canadensis), pair apparently 
with young June 14. They ran around me with dropping wings; Coot, two nests; June 14; Lesser Yellowlegs, downy young with narent, June 14; Black Tern, two nests, June 14 (1) 1 egg, (2) 3 eggs; and a third nest June 15,1 egg.

A $i$ Snowden I observed 125 Redwings and 11 Brewer's Blackbirds. Sparrows were much more abund- ant here than at Fishing Lake and some species more common than at Nipawin. In three full days I observed: Savannah Sparrows (22); LeConte's (39); Vesper (11 and nest with 4 eggs); Junco (2); Chipping Sparrow (2); Clay-colored (33); White-throated (2); Lincoln's (4); Swamp (3); Song (14 and two nests -4 eggs and 5 eggs).

\section{Game Act Revised To Protect Hawks And Owls}

In the June, 1960 issue of the Blue Jay we inserted a brief notice of the amendment to the Game Act offering further protection to hawks and owls. Members of our society have since asked us to publish the amendment in full.

Section 10 of the Game Act for the Province of Saskatchewan was amended March, 1960, to read as follows:

"(1) Subject to subsections (2) and (3), no person shall hunt, take, shoot at, wound or kill any game bird or any other bird that is wild by nature and in a state of nature, except crows, magpies, blackbirds, cowbirds, grackles, English sparrows and such other birds as may be designated by the Lieutenant Governor in Council, unless he is expressly authorized to do so by this Act or by a subsisting licence or permit issued to him pursuant to this Act.

"(2) Notwithstanding subsection (1), a person may, without such licence or permit, hunt, take, shoot at, wound or kill snowy owls, great horned owls and goshawks during the period from the first day of November in any year to the last day of March in the following year, both dates inclusive, unless with respect to any such period or any portion of any such period the Lieutenant Governor in Council by order declares that this subsection shall not apply during that period or portion.

"(3) Notwithstanding subsection (1) lbut otherwise subject to this Act and the regulations, an owner or occupant of any land outside a city, town, village or hamlet, actually domiciled and living upon any part of such land, may hunt, take, shoot at, "wound or kill game birds within the limits of such land without a licence or permit during open seasons."

Formerly, Section 10 read in part as follows:

“(1) Subject to subsection (2), no person shall hunt, take, shoot at, wound or kill any game bird or any other bird which is wild by nature and in a state of nature, except crows, magpies, snowy owls, great horned owls, goshawks, pigeon hawks, duck hawks, Cooper's hawks, sharp-shinned hawks, blackbirds, cowbirds, grackles, English sparrows, cormorants and such other birds as may be designated by the Lieutenant Governor in Council, unless he is expressly authorized to do so by this Act or by a subsisting licence or permit issued to him pursuant to this Act."

Subsection 3 of section 10a, which parmits the landowner to protect his stock and poultry against depredation by hawks and owls, reads as follows:

"(3) Northing in subsection (1) or (2) shall prevent 'a person from hunting, taking, shooting at, wounding or killing any wild animal or wild bird in a building in which poultry or domestic animals are kept or within six hundred feet from such building or from a hive where domestic bees are kept or for the purpose of protecting live stock or poultry on land owned or occupied by him." 